\title{
PERAN PERBANKAN SYARIAH TERHADAP UMKM SELAMA PANDEMI COVID-19 (STUDI KASUS BANK SYARIAH INDONESIA KC MEDAN)
}

\author{
Nasrun Ritonga \\ Universitas Al-Washliyah Medan \\ Email: nasrunritonga03@yahoo.com \\ Riny Viri Insy Sinaga \\ Universitas Al-Washliyah Medan \\ Email: Riny30vinsi@gmail.com
}

\begin{abstract}
Bank Syariah Indonesia performs the function of a bank as a place to save and distribute funds from the public to assist development in Indonesia. The existence of a bank is also highly dependent on the public's trust. The higher the public trust, the higher the public awareness to save their money in the bank and use other services from the bank. Small and medium enterprises (MSMEs) are one of the leading driving forces in the development of the manufacturing industry. The movement of the MSME sector is vital for creating economic growth andemployment.This study aims to determinethe role of Islamic banking in MSME act ors during the COVID-19 pandemic, this research was conducted at Bank Syariah Indonesia KC Ahmad Yani Medan. Research is using the methods of descriptive kualitatif and data used are primary data. Instruments that are used in primary data. Instruments that are used in primary data are interviews with speakers from Bank Syariah Indonesia KC Ahmad Yani Medan. From the research it can be known that Bank Syariah Indonesia KC Ahmad Yani Medan helped distribute the programs of government, namely Kredit Usaha Rakyak (KUR) to encourage perpetrators of MSMEs in future pancemic, wirh the help of customers who already receive disbursement of funds financing before a pandemic to provide relaxation or relief from paying installments.
\end{abstract}

Keywords: Islamic Banking, MSMEs, Covid-19

\begin{abstract}
Abstrak
Bank Syariah Indonesia menjalankan fungsi bank sebagai tempat menyimpan dan menyalurkan dana dari masyarakat untuk membantu pembangunan di Indonesia. Eksistensi suatu bank juga sangat tergantung pada kepercayaan masyarakat tersebut. Semakin tinggi kepercayaan masyarakat, semakin tinggipula kesadaran masyarakat untuk menyimpan uangnya ke bank dan menggunakan jasa-jasa lain dari bank.Usaha kecil dan menengah (UMKM) merupakan salah satu kekuatan pendorong terdepan dalam pengembangan industri manufaktur. Gerak sektor UMKM amat vital untuk menciptakan pertumbuhan ekonomi dan lapangan kerja. Penelitian ini bertjuan untuk mengetahui peran perbankan syariah terhadap pelaku UMKM selama masa pandemi covid-19, penelitian ini dilakukan pada Bank Syariah Indonesia KC Ahmad Yani Medan. Penelitian ini menggunakan metode deskriptif kualitatif dan data yang digunakan adalah data primer. Instrumen yang digunakan dalam data primer adalah wawancara dengan narasumber dari Bank Syariah Indonesia KC Ahmad Yani Medan. Dari penelitian ini dapat diketahui bahwa Bank Syariah Indonesia KC Ahmad Yani Medan
\end{abstract}


turut menyalurkan program pemerintah yaitu Kredit Usaha Rakyat (KUR) untuk mendorong pelaku UMKM pada masa pandemi Covid-19, dengan membantu nasabah yang sudah mendapatkan pencairan dana pembiayaan sebelum pandemi dengan memberikan relaksasi atau keringanan membayar angsuran.

Kata Kunci: Perbankan Syariah, UMKM, Covid-19

\section{Pendahuluan}

Menurut undang-undang No 21 Tahun 2008 tentang perbankan syariah dalam penelitian Trisadini (2014) ${ }^{\mathrm{i}}$ menyatakan bahwasanya perbankan syariah adalah "segala sesuatu yang menyangkut tentang Bank Syariah dan Unit Usaha Syariah, mencakup kelembagaan, kegiatan usaha, serta cara dan proses dalam melaksanakan kegiatan usahanya". Sedangkan pengertian bank adalah badan usaha yang menghimpun dana dari masyarakat dalam bentuk simpanan dan menyalurkannya kepada masyarakat dalam bentuk kredit atau dalam bentuk lainya dalam rangka meningkatkan taraf hidup masyarakat.

Sebagaimana bank pada umumnya Bank Syariah Indonesia menjalankan fungsi bank sebagai tempat menyimpan dan menyalurkan dana dari masyarakat untuk membantu pembangunan di Indonesia umumnya dan di Kota Medan khususnya. Eksistensi suatu bank juga sangat tergantung pada kepercayaan masyarakat tersebut. Semakin tinggi kepercayaan masyarakat, semakin tinggipula kesadaran masyarakat untuk menyimpan uangnya ke bank dan menggunakan jasa-jasa lain dari bank.

Usaha kecil dan menengah (UMKM) merupakan salah satu kekuatan pendorong terdepan dalam pengembangan industri manufaktur. ${ }^{\text {ii }}$ Gerak sektor UMKM amat vital untuk menciptakan pertumbuhan ekonomi dan lapangan kerja. UMKM cukup pleksibel dan dapat dengan mudah beradaptasi dengan pasang surut dan arah permintaan pasar. Mereka mampu menciptakan lapangan pekerjaan lebih cepat dibandingkan sektor usaha lainnya, juga mereka cukup terdiversifikasi dan memberikan kontribusi penting dalam ekspor dan perdagangan.

World bank menyatakan bahwa negara yang makmur setidaknya terdapat $2 \%$ dari jumlah penduduknya yang berpotensi sebagai wirausaha. Berdasarkan asumsi ideal tersebut, maka kondisi Indonesia masih jauh tertinggal. Berdasarkan data Kementrian Koperasi dan Usaha Kecil Menengah jumlah pengusaha Indonesia Per Januari 2012 sebesar $1.56 \% .3$ Terkait dengan rendahnya rasio wirausaha di Indonesia ini, maka berbagai upaya dalam konteks praktis dan akademis perlu kita kembangkan dalam upaya menumbuhkan minat serta meningkatkan kapasitas kewirausahaan yang sudahada.

Menurut Suryana (2013) $)^{\mathrm{iii}}$, esensi dari eksistensi usaha kecil dalam perekonomian antara 
242 AT-TAWASSUTH:Jurnal Ekonomi Islam, Volume VI No. II

Juli-Desember 2021: 240 - 253

lain: (1) Sebagai alat untuk memperkokoh perekonomian nasional melalui berbagai keterkaitan usah; (2) usaha kecil berfungsi sebagai transformator antar sektor yang mempunyai kaitan ke depan dan belakang; (3) usaha kecil dapat meningkatkan efisiensi ekonomi, khususnya dalam menyerap sumber daya yang ada; (4) usaha kecil sebagai sarana pendistribusian pendapatan nasional dan alat pemerataan berusaha (wealth creation process), karena jumlahnya tersebar diseluruh tanah air. Terlepas dari potensi keunggulan UMKM seperti dipaparkan di atas, UMKM di Indonesia juga memiliki banyak kelemahan, baik secara struktural maupun kultural. Kelemahan di bidang manajemen, organisasi, teknologi, permodalan, operasional dan teknis di lapangan, terbatasnya akses pasar, kendala perizinan, serta biaya-biaya non-teknis di lapangan yang sulit untuk dihindarkan. Dibutuhkan kerja keras, komitmen serta kesungguhan untuk membenahi dan meminimalisasi kendala-kendala seperti yang dijelaskan di atas.

Menurut Sri winarni dalam penellitian Supriadi $(2018)^{\mathrm{iv}}$ mengidentifikasikan permasalahan umum yang dihadapi oleh UMKM adalah: (1) kurang permodalan; (2) kesulitan dalam pemasaran; (3) persaingan usaha ketat; (4) kesulitan bahan baku; (4) kurang teknis produksi dan keahlian; (6) keterampilan manajerial kurang; (7) kurang pengetahuan manajemen keuangan; dan (8) iklim usaha yang kurang kondusif (perijinan, perundangan). Salah satu faktor yang merupakan kendala bagi tumbuh kembang UMKM di Indonesia adalah masalah permodalan usaha. Dari fenomena diatas, maka penulis tertarik untuk meneliti sejauh mana perbankan syariah berperan dalam mendorong Usaha Mikro, Kecil dan Menengah (UMKM).

\section{Kajian Teori}

Bank Islam atau selanjutnya disebut dengan bank syariah, adalah bank yang beroperasi dengan tidak mengandalkan pada bunga. Bank Islam atau biasa disebut dengan bank tanpa bunga, adalah lembaga perbankan yang operasional dan produknya sesuai dengan prinsip Islam.

Berbicara tentang peranan sesuatu, tidak dapat dipisahkan dengan fungsi dan kedudukan sesuatu itu. Diantara peranan bank Islam adalah: ${ }^{\mathrm{v}}$

a.Memurnikan operasional perbankan syariah sehingga dapat lebih meningkatkan kepercayaan masyarakat

b. Meningkatkan kesadaran syariah umat Islam sehingga dapat memperluas segmen dan pangsa pasar perbankan syariah 
c.Menjalin kerja sama dengan para ulama karena bagaimanapun peranulama, khususnya di Indonesia, sangat dominan bagi kehidupan umat Islam

Perbankan Islam atau disebut juga perbankan syariah berbeda dengan perbankan konvensional. Bank syariah terikat dengan ketentuan-ketentuan yang ada dalam al-Qur'an dan al- Hadist. Transaksi-transaksi pada perbankan syariah harus terhindar dari interest (riba) dan kontrak-kontrak yang mengandung ketidakpastian (gharar dan maysir), menekankan pada prinsip bagi hasil dan risiko, mengutamakan investasi pada sektor ekonomi halal dan harus didasari pada transaksi riil (asset-based). ${ }^{\mathrm{vi}}$

Keberadaan industri perbankan syariah di Indonesia telah mengalami peningkatan dan pengembangan yang signifikan dalam kurun waktu tiga dekade ini. Inovasi produk, peningkatan layanan, serta pengembangan jaringan menunjukkan tren yang positif dari tahun ke tahun. Bahkan, semangat untuk melakukan percepatan juga tercermin dari banyaknya Bank Syariah yang melakukan aksi korporasi. Tidak terkecuali dengan Bank Syariah yang dimiliki Bank BUMN, yaitu Bank Syariah Mandiri, BNI Syariah, dan BRI Syariah. ${ }^{\text {vii }}$

Bank Syariah Indonesia mempunyai tugas yaitu memegang fungsi Intermediasi. Tujuan intermediasi disini maksudnya Bank Syariah Indonesia merupakan perantara antara pihakpihak yang mengalami surplus dana dan pihak yang mengalami deficit dana. ${ }^{\text {vii }}$ Bank Syariah Indonesia dalam aktifitasnya melaksanakan langsung penyediaan kebutuhan nasabah yang diperlukan dan sesuai dengan aturan muamalah dengan kreditor bagi hasil.Dan tujuan Bank Syariah Indonesia harus disesuaikan dengan bermua'alat menurut ketentuan syariat Islam serta situasi di Indonesia, baik dibidang ekonomi, sosialbudaya, hukum maupun politik ${ }^{\text {ix }}$ Adapun tujuan umum Bank mandiri syariah Indonesia adalah sebagai berikut:

1.Meningkatkan kualitas kehidupan sosial masyarakat Indonesia, sehingga akan semakin berkurang kesenjangan sosial ekonomi, sebagai akibat dari praktek- praktek kegiatan ekonomi yang tidakIslami.

2.Meningkatkan partisipasi masyarakat dalam proses pembangunan terutama dalam bidang ekonomi keuangan yang selama ini partisipasi masyarakat memanfaatkan lembaga perbankan kurang sebagai akibat dari sikap keraguan terhadap hukum bungabank.

3.Mengembangkan lembaga bank dan sistem perbankan yang sehat berdasarkan efisiensi dan keadilan, sehingga mampu meningkatkan partisipasi masyarakat untuk menggalakan ekonomi rakyat, dengan antara lain memperluas jaringan perbankan kedaerah-daerah pedesaan yangterpencil. 
4.Mendidik dan membimbing masyarakat untuk berfikir secara ekonomi berlaku bisnis dan meningkatkan kualitas hidupmasyarakat.

Untuk menyediakan dana bagi kelancaran usaha, PT. Bank Syariah Indonesia Kota Medan menjalankan usaha dengan menawarkan produk-produk perbankan kepada para nasabah yang sekaligus menjadi konsumen dari produk-produk dan jasa yang ditawarkan. Pada dasarnya, produk yang ditawarkan oleh perbankan syari'ah dapat dibagi menjadi tiga bagian besar diantaranya adalah produk penyaluran dana (financing), produk penghimpun dana (funding), Produk jasa(divisi).

\section{Pengertian Usaha Mikro Kecil dan Menengah (UMKM)}

Beberapa pakar manajemen yang menulis tentang usaha kecil tidak memberikan batasan yang tegas. Mereka hanya memberikan indikator sebagai tolak ukur. Tolak ukur yang lazim digunakan antara lain jumlah kekayaan, seperti uang tunai, persediaan, tanah, mesin untuk produksi dan sumber daya lainnya yang dimiliki. Kemudian jumlah besarnya penyertaan yang dianggap sebagai modal kerja. Indikator lain adalah jumlah total penjualan dalam setahun dan jumlah pegawai yang dipekerjakan. Indikator ini masih harus dikaitkan dengan jenis dan sifat bidang apa usaha tersebut dijalani. Sebagai contoh ukuran indikator untuk usaha yang bergerak di bidang pabrikasi, tentu tidak sama dengan indikator yang digunakan untuk bidang usaha pedagang besar. ${ }^{\mathrm{x}}$

Menurut Siropolis dalam bukunya yang berjudul small business management yang dikutip oleh Mulyadi Nitisusastro, ${ }^{\text {xi }}$ bahwa yang masuk dalam kategori usaha kecil antara lain usaha yang dijalankan oleh pasangan suami istri, seperti warung makan atau toko kecil disekitar perumahan. Keputusan Menteri Keuangan RI nomor 316/KMK.616/1994 tentang pedoman pembinaan usaha kecil dan koperasi melalui pemanfaatan dana dari bagian laba Badan Usaha Milik Negara (BUMN). Keputusan tersebut membahas apa yang dimaksud denga usaha kecil dan kemudian didefinisikan sebagai perorangan atau badan usaha yang telah melakukan kegiatan usaha dengan omzet pertahun setinggi-tingginya Rp. 600.000.000,

Sektor perbankan syari'ah sebagai lembaga keuangan yang mengemban misi bisnis (tijarah), sekaligus misi sosial (tabarru) sudah seyogyanya mampu memberikan kontribusi bagi pengembangan sektor UMKM dimaksud. Untuk kepentingan UMKM suatu bank syari'ah hendaknya mampu secara cermat mengetahui kebutuhan nyata yang ada pada UMKM yang bersangkutan. Hal ini penting karena karakteristik produk pembiayaan yang ada pada perbankan syariah bervariasi dan masing-masing hanya menjawab pada kebutuhan 
tertentu. Adapun beberapa motif dan kebutuhan yang ada pada nasabah debitur yang dalam hal ini adalah UMKM dan produk perbankan syariah yang sesuai dapat dikategorikan antara lain sebagai berikut:

1. UMKM yang membutuhkan adanya barang modal sebagai sarana dalam prosesusaha.

2. UMKM dalam tahap pendirian yang membutuhkan modal kerja dan UMKM yang membutuhkan tambahan modal untuk kepentingan ekspansi usaha. Menyikapi adanya hal ini pihak bank syariah dapat memberikan pembiayan berdasarkan akad bagi hasil berupa pembiayaan mudharabah atau pembiayaanmusyarakah.

Strategi Perbankan Syariah Pada Saat Pandemi COVID-19

Penyakit Coronavirus 2019 (COVID-19) adalah penyakit menular yang disebabkan oleh sindrom pernapasan akut coronavirus 2 (SARS-CoV-2). Penyakit ini pertama kali diidentifikasi pada Desember 2019 di Wuhan,ibukota provinsi Hubei China, dan sejak saat itu menyebar secara global, menyebabkan pandemi coronavirus 2019-2020 yang sedang berlangsung. ${ }^{\text {xii }}$

Menurut analisis dan riset yang dikemukakan oleh J.P Morgan ada 3 risiko yang membayangi industri perbankan dalam masa pandemic covid-19, antara lain penyaluran kredit yang terhambat /macet, penurunan kualitas aset bank dan pengetatan margin atau pendapatan bunga bersih bank. ${ }^{\text {xiii }}$

Secara substansional, perbankan syariah memiliki fungsi intermediasi. Untuk mengaktifkan dan menjalankan fungsi tersebut secara efektif dan efisien, ada dua aktifitas bank yang harus dioptimalkan dalam pengoperasiannya yaitu penghimpunan dana dari masyarakat, berfungsi sebagai dana pihak ketiga dan penyaluran kembali dana dalam bentuk pembiayaan. Penyaluran pembiayaan murabahah perbankan syariah, lebih diutamakan dan difokuskan kepada para pelaku UMKM, karena melihat peran dan fungsi UMKM terhadap pertumbuhan ekonomi secara nasional serta mengurangi jumlah kemiskinan yang beredar dimasyarakat. ${ }^{\text {xiv }}$

\section{Metode Penelitian}

\section{LokasiPenelitian}

Penelitian ini beralokasi pada PT. Bank Syariah Indonesia KC. Ahmad Yani yang terletak di Jl. Jend. Ahmad Yani No. 100, Kesawan, Kec. Medan Baru, Kota Medan. Adapun alasan pemilihan lokasi ini dikarenakan PT. Bank Syariah Indonesia merupakan bank korporasi dari 
3 perbankan syariah di Indonesia yaitu Bank Mandiri Syariah, BNI Syariah, dan BRI Syariah dengan total aset 234,4 Triliun rupiah.

2. Subjek dan ObjekPenelitian

Adapun subjek dalam penelitian ini adalah nasabah PT. Bank Syariah Indonesia KC. Ahmad Yani di Jl. Jend. Ahmad Yani Kota Medan. Sedangkan objek dalam penelitian ini adalah nasabah dan karyawan bank.

3. Populasi danSampel

Dalam penelitian ini yang dijadikan populasi adalah pimpinan, karyawan/i, dan nasabah yang menerima pembiayaan. Jumlah nasabah yang menerima pembiayaan berjumlah 1.154. Dikarenakan banyaknya nasabah untuk pembiayaan tersebut, maka sampel yang diambil adalah $10 \%$ dari jumlah populasi, sehingga jumlah nasabah untuk pembiayaan tersebut yang diambil adalah 115 orang dan pimpinan, karyawan/i berjumlah 3 orang, sehingga jumlah sampel adalah 118 orang. Adapun sampel yang ditentukan dengan menggunakan Purposive Sampling, yaitu sampling dimana elemen yang dimasukan dalam sampel dilakukan dengan sengaja dengan catatan bahwa sampel tersebut representative atau mewakili populasi.

4. SumberData

Dalam penelitian ini ada dua data yang dikumpulkan terdiri dari data primer dan data sekunder, yaitu: a. Data Primer. Data primer yaitu data yang diperoleh langsung dari lapangan berupa tanggapan responden yang diperoleh melalui angket, obsevasi, dokumentasi dan wawancara dengan karyawan PT. Bank Syariah Indonesia KC. Ahmad Yani Kota Medan. Data primer disebut juga dengan data asli atau data baru. b. Data Sekunder Data sekunder yaitu data yang diperoleh dari literatur yang berhubungan langsung dengan masalah yang diteliti. Data sekunder ini disebut juga dengan data yang tersedia.

5. Teknik PengumpulanData

Penelitian ini merupakan salah satu bentuk penelitian lapangan, dimana data yang dipaparkan diperoleh dari hasil penelitian lapangan sebagai data primer. Sementara data yang berasal dari perpustakaan dijadikan sebagai data sekunder dan data dokumentasi lainnya. Dalam memperoleh data lapangan digunakan dengan cara: a. Observasi yaitu suatu teknik pengumpulan data yang dilakukan secara langsung baik terhadap lokasi penelitian secara umum, maupun keadaan responden itu sendiri. b. Metode dokumentasi merupakan suatu cara pengumpulan data yang menghasilkan catatan penting yang 
berhubungan dengan masalah yang akan diteliti, sehingga akan diperoleh data yang lengkap, sah dan bukan berdasarkan perkiraan. Metode ini digunakan untuk mengumpulkan data yang sudah tersedia dalam catatan dokumen PT. Bank Syariah Indonesia KC. Ahmad Yani Kota Medan. c. Wawancara yaitu suatu teknik pengumpulan data yang dilakukan dengan cara berdialog atau tanya jawab langsung dengan narasumber untuk mendapatkan data dan informasi yang akurat dan diperlukan sesuai dengan permasalahan yang diteliti agar data jadi lebih lengkap. d. Angket yaitu serangkaian daftar pertanyaan yang disusun secara sistematis, kemudian dikirim dan diisi oleh responden. Setelah diisi, angket angket akan dikirim kembali atau dikembalikan kepada petugas atau peneliti. Dengan teknik ini penulis menyebarkan sejumlah pertanyaan tertulis yang disusun dalam daftar dan menyesuaikan dengan kajian penelitian. Jumlah angket yang disebarkan sesuai dengan sampel yang dibutuhkan yaitu 118 orang responden.

6. Teknik AnalisisData

Untuk mengetahui gambaran permasalahan yang akan dibahas, maka dilakukan analisa data. Dalam hal ini penulis menggunakan metode deskriptif analisis, yaitu menggambarkan objek yang dimiliki atau menggambarkan hasil pengamatan dan wawancara yang telah diperoleh, serta membahasnya sehingga jelas terlihat fakta-fakta yang berhubungan dengan masalah yang diteliti. Selanjutnya akan dibandingkan dengan teori yang ada, kemudian dari analisa inilah dapat ditarik kesimpulan dan saran-saran.

\section{Hasil dan Pembahasan}

Perbankan syariah sebagai salah satu wujud gerakan ekonomi syariah mendorong timbulnya perilaku ekonomi yang etis di kalangan masyarakat Indonesia. Ekonomi syariah adalah ekonomi yang berpihak kepada kebenaran dan keadilan dan menolak segala bentuk perilaku ekonomi yang tidak baik seperti sistem riba, spekulasi, danketidakpastian. Secara substansional, perbankan syariah memiliki fungsi intermediasi. Untuk mengaktifkan dan menjalankan fungsi tersebut secara efektif dan efesien, ada dua aktifitas bank yang harus dioptimalkan dalam pengoperasiannya yaitu penghimpunan dana dari masyarakat, berfungsi sebagai dana pihak ketiga dan penyaluran kembali dana dalam bentuk pembiayaan. Bertujuan agar berdampak pada dua sisi, sisi yang pertama stabilnya tingkat kesehatan perbankan syariah, dan sisi kedua berdampak positif dari aktifitas yang dilakukan oleh perbankan syariah terhadap perekonomian melalui penyaluran pembiayaan ke masyarakat. 
Penyaluran pembiayaan murabahah perbankan syariah, lebih diutamakan dan difokuskan kepada pelaku UMKM, karena melihat peran dan fungsi UMKM terhadap pertumbuhan ekonomi secara nasional serta mengurangi jumlah kemiskinan yang beredar di masyarakat. Keberadaan bank syariah dalam sistem perekonomian di sektor perbankan di Indonesia merupakan bank umum yang beralaskan prinsip syariah pada operasionalnya, sedangkan prinsip syariah itu sendiri ialah, aturan perjanjian hukum Islam antara bank dan pihak (nasabah) yang menyimpan dana, pembiayaan kegiatan usaha yang lain dan sesuai dengan ajaran syariah, adapun macam-macam kegiatan yang berada di perbankan syariah antara lain:

a. Pembiayaan berdasarkan prinsip bagi hasil (Mudharabah)

b. Pembiayaan berdasarkan prinsip penyeretan modal (Musyarakah)

c. Prinsip jual beli barang dengan memperoleh keuntungan (Murabahah)

d. Pembiayaan barang modal berdasarkan prinsip sewa menyewa (Ijarah)

Bank Mandiri Syariah KC Ahmad Yani Medan berperan penting dalam mendorong pertumbuhanUsahaMikro,KecildanMenengah(UMKM)sesuaidenganperaturanpemerintahPOJ K nomor 11 tahun 2020 untuk mendorong pertumbuhan UMKM. Dalam peraturan POJK nomor 11 tahun 2020 sesuai dengan pasal 7 ayat 1 Bank dapat memberikan kredit pembiayaan atau penyediaan dana lain yang baru kepada debitur yang terkena dampak COVID-19 termasuk debitur usaha mikro, kecil, dan menengah. ${ }^{\mathrm{xv}}$ Bank syariah sebagai lembaga intermediasi masyarakat yang memiliki modal dengan yang membutuhkan modal dituntut untuk dapat melakukan aktivitasnya di tengah pandemi COVID-19. Perbankan syariah berperan strategis dalam pembangunan ekonomi Indonesia. Perbankan Syariah harus cepat beradaptasi dengan membuat strategi yang kreatif dan inovatif untuk bertahan dalam Pandemi COVID-19. Tantangan yang dihadapi perlu untuk diubah menjadi sebuah kesempatan menjadi lebih baik. Selain itu masa berakhirnya pandemi belum bisa diketahui.

Pembiayaan UMKM adalah pembiayaan yang diberikan oleh lembaga keuangan syariah berbasis usaha, artinya modal digulirkan untuk modal kerja. Pembiayaan bank syariah pada UMKM mencerminkan kepedulian terhadap peningkatan inklusi keuangan melalui keuangan syariah.SalahsatuprodukpembiayaantersebutadalahKUR(KreditUsahaRakyat),yaitu salah satu program pemerintah yang diberikan kepada para pelaku UMKM (Usaha Mikro Kecil Menengah) yang bergerak di sektor usaha produktif seperti pertanian, perikanan, kelautan, perindustrian, kehutanan, dan jasa keuangan simpan pinjam untuk pembiayaan modal kerja 
dan investasi. Nawai \& Shariff ${ }^{x v i}$, menyebutkan bahwa pembiayaan mikro dapat membantu pengusaha mikro untuk meningkatkan bisnis mereka.

BankSyariahIndonesiaKCAhmadYaniMedanturutmenyalurkanprogrampemerintah yaitu Kredit Usaha Rakyat (KUR) untuk mendorong pelaku UMKM pada masa pandemi Covid-19, dengan membantunasabahyangsudahmendapatkanpencairandanapembiayaansebelumpandemi dengan memberikan relaksasi atau keringanan membayar angsuran. Jika nasabah terkena dampak Covid-19 maka angsuran yang dibayarkan sesuai dengan kemampuan nasabah tersebut pada saat terkena dampak Covid-19. Untuk nasabah yang ingin mengajukan pembiayaan maka proses pembiayaan dapat dipermudah asalkan usaha itu tidak terlalu terkena dampak secarasignifikan.

Peraturan POJK tahun 2020 pasal 5 ayat 2 menyebutkan Restrukturisasi kredit atau pembiayaansebagaimanadimaksudpadaayat(1)dapatdilakukanterhadapkreditataupembiayaan yang diberikan sebelum maupun setelah debitur terkena dampak penyebaran coronavirus disease 2019 (COVID-19) termasuk debitur usaha mikro, kecil, dan menengah. Dalam upaya memutus mata rantai penyebaran virus Covid-19 dengan menerapkan social distancing atau pembatasan social, Bank Syariah Indonesia KC Ahmad Yani Medan memberikan kemudahan bagi para nasabah yang ingin mengajukan pembiayaan bisa mendaftar secara online melalui Mobile Banking.

Menurut analisis dan riset yang dikemukakan oleh J.P Morgan ada tiga risiko yang membayangi industri perbankan dalam masa pandemi covid-19, antara lain penyaluran kredit yang terhambat/macet, penurunan kualitas aset bank dan pengetatan margin atau pendapatan bunga bersih bank. ${ }^{\text {xvii }}$

Ada beberapa faktor yang menjadi risiko dalam pembiayaan di Bank Syariah Indonesia, di antaranya:

a. Nasabah telat membayar angsuran akibat terjadinya penurunan omsetnasabah.

b. Karakter dari nasabah yang tidak kooperatif; mempunyai biaya untuk membayar angsuran tetapi biaya tersebut tidak dibayarkan kepada bank melainkan untuk memenuhi kebutuhan konsumtif seperti berbelanja danlain-lain.

c. Nasabah yang memberikan utang dagangannya kepada orang lain, ketika orang lain telatmembayar kepada nasabah otomatis nasabah menjadi telat membayar angsuran kepadaBank.

Cara penanganan yang dilakukan Bank Syariah Indonesia KC Ahmad Yani Medan dalam menyikapi risiko pembiayaan tersebut di antaranya : 
a. Selalu berkomunikasi setiap bulan dengan nasabah untuk menanyakan usahanya apakah mengalami penurunan atau kemajuan. Jika nasabah mengalami penurunan omset usaha dan belum mampu membayar angsuran maka pihak bank memberikan solusi dengan upaya menggunakan saldo yang ada di rekening nasabah untuk membayarangsuran.

b. Satu minggu sebelum jatuh tempo tanggal pembayaran angsuran pihak bank mengingatkan kepada nasabah untuk melakukan kewajiban membayarangsuran.

Kepada nasabah yang telah diingatkan tetapi masih tidak membayar angsuran pihak bank memberikan surat pemberitahuan utang. Setelah satu minggu surat pemberitahuan utang diberikan kepada nasabah tetapi tidak ada respon dari nasabah, pihak bank memberikan surat peringatan (SP) satu kepada nasabah. Satu minggu setelah SP satu diberikan tetapi nasabah masih tidak membayar angsuran pihak bank memberikan SP dua. Selang satu minggu kemudian masih belum ada tanggapan dari nasabah maka pihak bank memberikan SP tiga dan terakhir pihak bank melakukan eksekusi lelang agunannasabah.

\section{Kesimpulan}

Bank Mandiri Syariah KC Ahmad Yani Medan berperan penting dalam mendorong pertumbuhanUsahaMikro,KecildanMenengah(UMKM)sesuaidenganperaturanpemerintahPOJ K nomor 11 tahun 2020 untuk mendorong pertumbuhan UMKM. Dalam peraturan POJK nomor 11 tahun 2020 sesuai dengan pasal 7 ayat 1 Bank dapat memberikan kredit pembiayaan atau penyediaan dana lain yang baru kepada debitur yang terkena dampak COVID-19 termasuk debitur Usaha Mikro, Kecil, Dan Menengah.

BankSyariahIndonesiaKCAhmadYaniMedanturutmenyalurkanprogrampemerintah $\quad$ yaitu Kredit Usaha Rakyat (KUR) untuk mendorong pelaku UMKM pada masa pandemi Covid-19, dengan membantunasabahyangsudahmendapatkanpencairandanapembiayaansebelumpandemi dengan memberikan relaksasi atau keringanan membayar angsuran. Jika nasabah terkena dampak Covid-19 maka angsuran yang dibayarkan sesuai dengan kemampuan nasabah tersebut pada saat terkena dampak Covid-19. Untuk nasabah yang ingin mengajukan pembiayaan maka proses pembiayaan dapat dipermudah asalkan usaha itu tidak terlalu terkena dampak secarasignifikan.

\section{Endnote}

iTrisadini Prasastina. Jurnal Ekonomi Volume 29 No 1, Hlm.2 
${ }^{i i}$ Kuncoro, Mudrajad. Ekonomika Industri Indonesia, (Yogyakarta: Andi,2013), Hlm. 23

iii Suryana. Ekonomi Keatif, Ekonomi Baru: Mengubah Ide dan Menciptakan Peluang. (Jakarta: SalembaEmpat, 2013), Hlm. 56

ivIbnu supriadi. Majalah ilmiah "Pelita Ilmu” STIA Pembangunan Jamber, Vol. 1 No. 1, 2018, Hlm.8

${ }^{v}$ Ode Kamarudin. Peran Perbankan Syariah dalam Penguatan Usaha Mikro di Kota Ambon. Tesis. 2019, Hlm 17

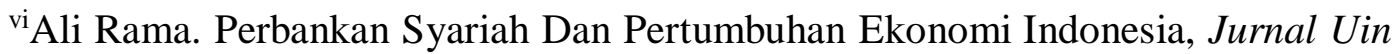
Syarif Hidayatullah Jakarta, Vol. 2, No. 1. 2013, Hlm 35

viihttps://www.bsi.co.id, diakses Maret 2021

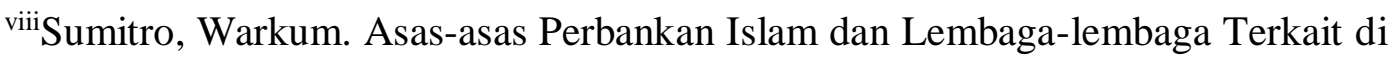
Indonesia. (Jakarta: PT RajaGrafindoPersada, 2004), hlm

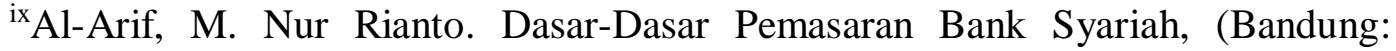
Alfabeta, 2010), Hlm.98

${ }^{x}$ Sudaryanto, Ragimun. Strategi Pemberdayaan UMKM Menghadapi Pasar Bebas Asean. (Yogyakarta: KedaulatanRakyat, 2011), Hlm. 77

${ }^{x i}$ Nitisusastro, Mulyadi, Kewirausahaan dan Manajemen Usaha Kecil, (Bandung: Alfabeta, 2009), Hlm 129

xiihttps://www.kompas.com/, diakses Juli 2021

xiii M. Ja'far Shiddiq Sunarya. Dampak Covid-19 terhadap lembaga Keuangan Syariah (Perbankan Syariah), Iqtishodia: Jurnal Ekonomi Syariah Vol, 5, N0.1. 2020, Hlm 13

${ }^{\text {xiv }}$ Al Imron dan Naf'an Tarihoram. Peranan Perbankan Syariah Terhadap Pengembangan UMKM pada Masa Pandemi COVID-19. (Banten: Media Madani, 2020), Hlm 58

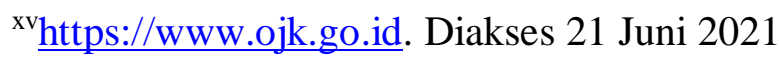

${ }^{x v i}$ Nawai, N. dan M.N.M Shariff. The Importance of Micro Financing to the Microentreprises Development in Malaysia. Asian Social Science. 2011, Hlm. 11

xvii M. Ja'far Shiddiq Sunariya. 2020. Dampak Covid-19 Terhadap Lembaga Keuangan Syariah (Perbankan Syariah., Iqtishodia: Jurnal Ekonomi Syariah Vol. 5, No.1, Hlm. 13 


\section{Daftar Pustaka}

Abdurrahman. 2003. Fungsi Intermediasi Perbankan di Daerah. Jakarta: PT Rineka Cipta

Amah, Nik. "Bank Syariah Dan Umkm Dalam Menggerakkan Roda Perekonomian Indonesia: Suatu Kajian Literatur

Al-Arif, M. Nur Rianto. 2010.Dasar-Dasar Pemasaran Bank Syariah. Bandung: Alfabeta.

Al-Imron dan Naf'an Tarihoram. 2020. Peranan Perbankan Syariah Terhadap Pengembangan UMKM pada Masa Pandemi COVID-19, Banten: Media Madani

https://www.bsi.co.id, diakses Maret 2021

https://www.ojk.go.id. Diakses 21 Juni 2021

https://www.kompas.com/, diakses Juli 2021

Kamarudin, Ode. 2019. Peran Perbankan Syariah dalam Penguatan Usaha Mikro di Kota Ambon. Tesis

Mudrajad, Kuncoro. 2013. Ekonomika Industri Indonesia, Yogyakarta: Andi

M. Ja'far Shiddiq Sunariya. 2020. Dampak Covid-19 Terhadap Lembaga Keuangan Syariah (Perbankan Syariah., Iqtishodia: Jurnal Ekonomi Syariah Vol. 5, No.1

Nitisusastro, Mulyadi. 2009. Kewirausahaan dan Manajemen Usaha Kecil. Bandung: Alfabeta

N, Nawaidan M.N.M Shariff. 2011. The Importance of Micro Financing to the Microentreprises Development in Malaysia. Asian Social Science

Obaidullah. 2008. Introduction to Islamic Microfinance, New Delhi: International Institute of Islamic Bussines and Finance

Prasastina, Trisadini. 2014 Jurnal Ekonomi Volume 29 No 1

Rama, Ali. 2013.Perbankan Syariah Dan Pertumbuhan Ekonomi Indonesia, Jurnal Uin Syarif Hidayatullah Jakarta,Vol. 2, No. 1

Shiddiq Sunarya, M. Ja'far. 2020. Dampak Covid-19 terhadap lembaga Keuangan Syariah (Perbankan Syariah). Iqtishodia: Jurnal Ekonomi SyariahVol, 5, N0.1

Soekarni, Muhammad.2014. "Dinamika Pembiayaan Perbankan Syariah Dalam Mengembangkan Dunia Usaha”. Jurnal Ekonomi dan Pembangunan Vol. 22 No. 1 
Nasrun Ritonga: Peran Perbankan Syariah... 253

Sudaryanto, Ragimun. 2011. Strategi Pemberdayaan UMKM Menghadapi Pasar Bebas Asean. Yogyakarta: KedaulatanRakyat.

Supriadi, Ibnu. 2018. Majalah ilmiah "Pelita Ilmu” STIA Pembangunan Jamber, Vol. 1 No. 1

Suryana. 2013. Ekonomi Keatif, Ekonomi Baru: Mengubah Ide dan Menciptakan Peluang. Jakarta: SalembaEmpat.

Warkum, Sumitro. 2004. Asas-asas Perbankan Islam dan Lembaga-lembaga Terkait di Indonesia. Jakarta: PT RajaGrafindoPersada. 